\title{
Neurofibromatosis type 1 associated with hypophosphatemic osteomalacia due to hypersecretion of fibroblast growth factor 23: a case report
}

Takahiko Obo ${ }^{1,2}$, Nobuyuki Koriyama ${ }^{1 *}$, Akinori Tokito ${ }^{1}$, Kazuma Ogiso ${ }^{1,2}$ and Yoshihiko Nishio ${ }^{2}$

\begin{abstract}
Background: Neurofibromatosis type 1 is characterized by multiple café au lait spots and cutaneous and plexiform neurofibromas, and is one of the most common autosomal dominant hereditary disorders caused by mutations of the neurofibromatosis type 1 tumor suppressor gene. Osteomalacia in neurofibromatosis type 1 is very rare and is characterized by later onset in adulthood. In humans, fibroblast growth factor 23 , which is a causative factor of tumor-induced osteomalacia, is not only a paracrine and autocrine factor, but is also a physiological regulator of phosphate balance in normal serum.
\end{abstract}

Case presentation: Our patient was a 65-year-old Japanese woman whose neurofibromas began to appear when she was in elementary school. At age 28 , she was diagnosed as having neurofibromatosis type 1 . A spinal compression fracture and multiple rib fractures were identified in 2012 and 2017, respectively. Her laboratory findings revealed hypophosphatemia due to renal phosphate wasting and a high serum level of fibroblast growth factor 23. Neurofibromas located on the surface of her right forearm and left upper arm, in which a slight abnormal accumulation of tracers was observed on ${ }^{111}$ indium-pentetreotide scintigraphy, were surgically removed, but there was no improvement in hypophosphatemia or serum fibroblast growth factor 23 after surgery. Therefore, we administered eldecalcitol, which also failed to produce improvement in abnormal data. Subsequent combination with dibasic calcium phosphate hydrate led to improvement in some of the abnormalities, including hypophosphatemia. Immunohistochemical staining using anti-human fibroblast growth factor 23 antibody revealed slightly positive results, however, only one out of three amplifications of the fibroblast growth factor 23 gene was observed by real-time polymerase chain reaction, and no clear fibroblast growth factor 23 gene expression in the resected neurofibromas could be confirmed.

Conclusions: We here describe a first rare case of a 65-year-old woman with neurofibromatosis type 1 associated with hypophosphatemic osteomalacia in which a high serum fibroblast growth factor 23 level was confirmed.

Keywords: Fibroblast growth factor 23, Tumor-induced osteomalacia, Neurofibromatosis type 1, Hypophosphatemia, 25-hydroxyvitamin $\mathrm{D}_{3}$

\footnotetext{
* Correspondence: koriyama.nobuyuki.wm@mail.hosp.go.jp

1 Department of Diabetes and Endocrine Medicine, National Hospital

Organization Kagoshima Medical Center, 8-1 Shiroyama-cho, Kagoshima 892-0853, Japan

Full list of author information is available at the end of the article
}

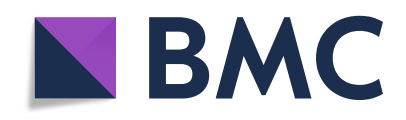

( ) The Author(s). 2020 Open Access This article is licensed under a Creative Commons Attribution 4.0 International License, which permits use, sharing, adaptation, distribution and reproduction in any medium or format, as long as you give appropriate credit to the original author(s) and the source, provide a link to the Creative Commons licence, and indicate if changes were made. The images or other third party material in this article are included in the article's Creative Commons licence, unless indicated otherwise in a credit line to the material. If material is not included in the article's Creative Commons licence and your intended use is not permitted by statutory regulation or exceeds the permitted use, you will need to obtain permission directly from the copyright holder. To view a copy of this licence, visit http://creativecommons.org/licenses/by/4.0/. The Creative Commons Public Domain Dedication waiver (http://creativecommons.org/publicdomain/zero/1.0/) applies to the data made available in this article, unless otherwise stated in a credit line to the data. 


\section{Background}

Neurofibromatosis type 1 (NF1) is characterized by multiple café au lait spots and cutaneous and plexiform neurofibromas (NFomas), and is one of the most common autosomal dominant hereditary disorders caused by mutations of the NF1 tumor suppressor gene (NF1) on chromosome 17 [1-3]. In addition, generalized skeletal abnormalities, such as mild short stature [4] and decreased bone mineral density (BMD) [5], are frequent in NF1. Osteomalacia in NF1, however, is very rare and is characterized by later onset in adulthood [6].

In humans, fibroblast growth factor 23 (FGF23), which is a causative factor of tumor-induced osteomalacia (TIO), is a 251 amino acid polypeptide hormone (32.5 $\mathrm{kDa}$ ) belonging to the fibroblast growth factor (FGF) family [7]. FGF23 can be amplified from the human heart, liver, thyroid/parathyroid, intestine, lymph node, thymus, and skeletal muscle and bone by the reverse transcription-polymerase chain reaction technique [7-9]. Furthermore, it was reported that FGF23 acts on sodium-phosphorus co-transporter in the renal tubule and inhibits $1 \alpha$-hydroxylation of 25-hydroxyvitamin $\mathrm{D}_{3}$ $\left(25(\mathrm{OH}) \mathrm{D}_{3}\right)$; thus, leading to renal phosphate leakage, hypophosphatemia, inappropriately normal or low $1 \alpha 25$ dihydroxyvitamin $\mathrm{D}_{3}\left(1 \alpha 25(\mathrm{OH})_{2} \mathrm{D}_{3}\right)$ levels, and decreased bone mineralization [10]. Hence, FGF23 is not only a paracrine and autocrine factor, but is also a physiological regulator of phosphate balance in normal serum [11].

Here, we report a rare case of a 65-year old woman with hypophosphatemic osteomalacia associated with NF1. Her serum FGF23 levels were elevated but no clear expression of FGF23 was confirmed in her surgically resected NFomas by immunohistochemical and molecular analysis.

\section{Case presentation}

Our patient was a 65-year-old Japanese woman whose NFomas began to appear when she was in elementary school. She was born without any perinatal anomalies. At age 28, she was diagnosed as having NF1. In 2012, a spinal compression fracture was identified during a visit to a local orthopedic surgeon for lumbago. In 2017, she visited a local orthopedic surgeon with a chief complaint of lateral chest pain, and multiple rib fractures were identified. Hence, she was referred to our department for endocrinological examination. Pregabalin $50 \mathrm{mg}$ was administered daily, and loxoprofen sodium hydrate 60 $\mathrm{mg}$ was used at the time of pain.

She was $147.1 \mathrm{~cm}$ tall, weighed $47.5 \mathrm{~kg}$, body mass index was $22.0 \mathrm{~kg} / \mathrm{m}^{2}$, body temperature was $36.6^{\circ} \mathrm{C}$, blood pressure was $105 / 72 \mathrm{mmHg}$, and pulse was 72 beats/minute and regular. She showed no mental retardation, and no pigmentation on her skin and oral mucosa.
Her cardiopulmonary examination was normal. She had no abnormal abdominal and neurological findings or skeletal abnormalities. Soft NFomas of various sizes were scattered all over her body, and relatively large masses approximately $4 \mathrm{~cm}$ in diameter were present on the surface of her right forearm and left upper arm (Fig. 1). Her eldest daughter has also been diagnosed as having NF1. She was a caregiver; our patient drank alcohol occasionally but did not smoke tobacco. Her serum levels of inorganic phosphorus (IP), $25(\mathrm{OH}) \mathrm{D}_{3}$, and maximum transport of phosphorus in the renal proximal tubules (TmP/GFR) were inappropriately low (Table 1 ). Serum alkaline phosphatase (ALP), intact parathyroid hormone (intact PTH), bone-specific alkaline phosphatase (BAP), tartrate-resistant acid phosphatase 5b (TRACP 5b), and undercarboxylated osteocalcin (ucOC) levels were all elevated. Her serum level of FGF23 was high. The results of total blood cell count and other biochemical parameters were almost within normal limits (Table 1). BMD using dual-energy X-ray absorptiometry of the second to fourth lumbar vertebrae (L2-4, total) and left femoral neck were $0.764 \mathrm{~g} / \mathrm{cm}^{2}$ and $0.504 \mathrm{~g} / \mathrm{cm}^{2}$, with a young adult mean (YAM) of $64 \%$ and $54 \%$, respectively. Computed tomography displayed no space occupying lesions other than NFomas on the body surface. Multiple areas

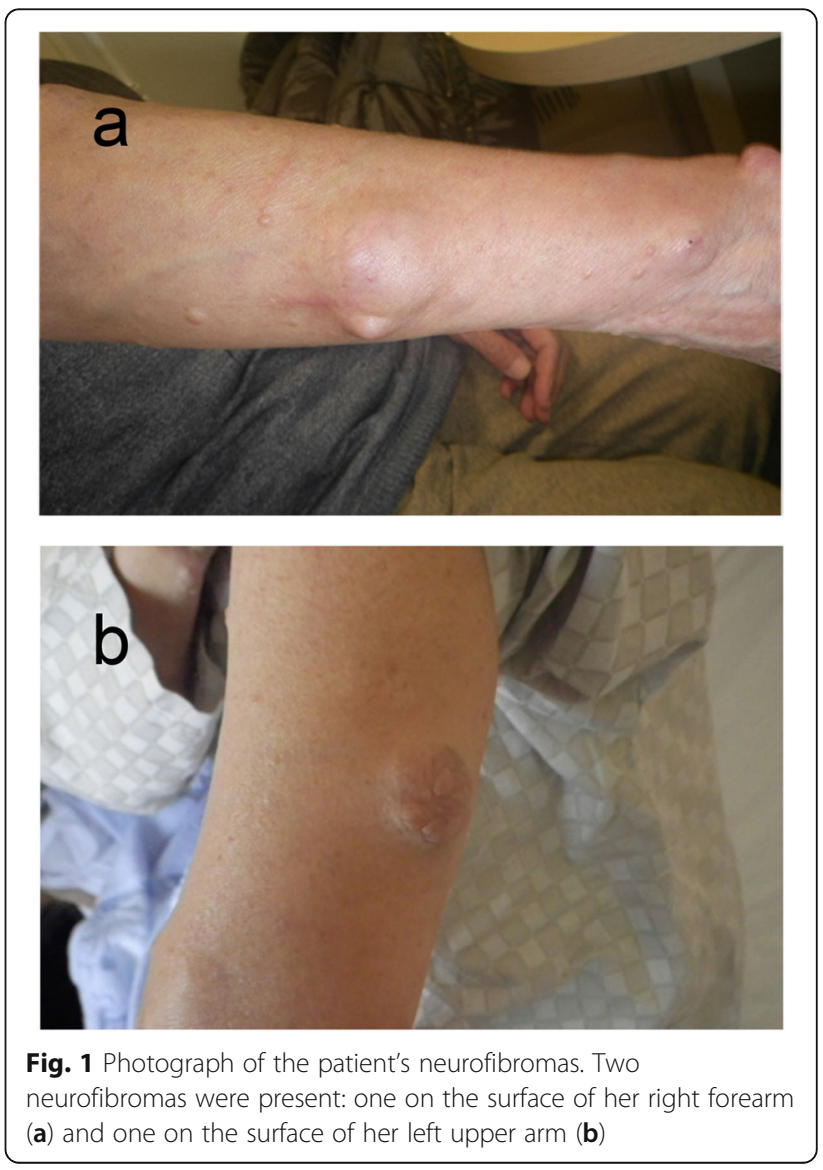


Table 1 Laboratory findings

\begin{tabular}{|c|c|c|c|c|}
\hline Inspection Item & & & & $\begin{array}{l}\text { Reference } \\
\text { range }\end{array}$ \\
\hline \multirow[t]{3}{*}{ Urine analysis } & Protein & $(-)$ & & \\
\hline & Glucose & $(-)$ & & \\
\hline & Occult blood & $(-)$ & & \\
\hline Urine biochemistry & $\mathrm{TmP} / \mathrm{GFR}$ & 1.77 & & $22-40$ \\
\hline \multirow[t]{4}{*}{ Peripheral blood } & WBC & 3270 & $/ \mu \mathrm{L}$ & \\
\hline & RBC & $409 \times 10^{4}$ & $/ \mu \mathrm{L}$ & \\
\hline & $\mathrm{Hb}$ & 11.5 & $\mathrm{~g} / \mathrm{dL}$ & \\
\hline & PLT & $24.6 \times 10^{4}$ & $/ \mu \mathrm{L}$ & \\
\hline \multirow[t]{18}{*}{ Biochemistry } & AST & 14 & $\mathrm{IU} / \mathrm{L}$ & \\
\hline & ALT & 11 & $\mathrm{IU} / \mathrm{L}$ & \\
\hline & $\mathrm{LDH}$ & 168 & $\mathrm{IU} / \mathrm{L}$ & \\
\hline & ALP & 641 & $\mathrm{IU} / \mathrm{L}$ & $106-322$ \\
\hline & $\gamma$-GTP & 26 & $\mathrm{IU} / \mathrm{L}$ & \\
\hline & T. Bil & 0.95 & $\mathrm{mg} / \mathrm{dL}$ & \\
\hline & Alb & 4.24 & $\mathrm{~g} / \mathrm{dL}$ & \\
\hline & $\mathrm{Na}$ & 144 & $\mathrm{mmol} / \mathrm{L}$ & \\
\hline & K & 3.4 & $\mathrm{mmol} / \mathrm{L}$ & $3.6-4.8$ \\
\hline & $\mathrm{Cl}$ & 106 & $\mathrm{mmol} / \mathrm{L}$ & \\
\hline & $\mathrm{Ca}$ & 8.8 & $\mathrm{mg} / \mathrm{dL}$ & \\
\hline & $\mathbb{I P}$ & 1.9 & $\mathrm{mg} / \mathrm{dL}$ & $2.7-4.6$ \\
\hline & $\mathrm{Mg}$ & 2.0 & $\mathrm{mg} / \mathrm{dL}$ & \\
\hline & BUN & 12.1 & $\mathrm{mg} / \mathrm{dL}$ & \\
\hline & $\mathrm{Cr}$ & 0.51 & $\mathrm{mg} / \mathrm{dL}$ & \\
\hline & eGFR & 90.4 & $\mathrm{~mL} / \mathrm{minu}$ & $\mathrm{e} / 1.73 \mathrm{~m}^{2}$ \\
\hline & FBG & 97 & $\mathrm{mg} / \mathrm{dL}$ & \\
\hline & $\mathrm{HbA}_{1 \mathrm{c}}$ & 5.2 & $\%$ & \\
\hline \multirow[t]{7}{*}{ Endocrinology } & Intact PTH & 123 & $\mathrm{pg} / \mathrm{mL}$ & $10-65$ \\
\hline & $25(\mathrm{OH}) \mathrm{D}_{3}$ & 14.0 & $\mathrm{ng} / \mathrm{mL}$ & $20-60$ \\
\hline & $1 \mathrm{a} 25(\mathrm{OH}) 2 \mathrm{D}_{3}$ & 57.2 & $\mathrm{pg} / \mathrm{mL}$ & $20-60$ \\
\hline & FGF23 & 57.0 & $\mathrm{pg} / \mathrm{mL}$ & $<30$ \\
\hline & BAP & 55.1 & $\mu \mathrm{g} / \mathrm{L}$ & $3.8-22.6$ \\
\hline & TRACP 5b & 996 & $\mathrm{mU} / \mathrm{dL}$ & $120-420$ \\
\hline & ucOC & 19.0 & $\mathrm{ng} / \mathrm{mL}$ & $<4.5$ \\
\hline
\end{tabular}

Alb albumin, $A L P$ alkaline phosphatase, $A L P$ alkaline phosphatase, $A L T$ alanine aminotransferase, $A S T$ aspartate aminotransferase, $B A P$ bone-specific alkaline phosphatase, BUN blood urea nitrogen, $C r$ creatinine, eGFR estimated glomerular filtration rate, $F B G$ fasting blood glucose, FGF23 fibroblast growth factor 23, $\gamma$-GTP $\gamma$-glutamyltransferase, $\mathrm{Hb}$ hemoglobin, $\mathrm{HbA}_{1 c}$ glycosylated hemoglobin, IP inorganic phosphorus, $L D H$ lactate dehydrogenase, $P L T$ platelets, $P T H$ parathyroid hormone, RBC red blood cells, T. Bil total bilirubin, TmP/GFR maximum transport of phosphate in the renal proximal tubules, TRACP $5 b$ tartrate-resistant acid phosphatase $5 \mathrm{~b}, \mathrm{u} O \mathrm{OC}$ undercarboxylated osteocalcin, WBC white blood cells, 1a25(OH)2D3 1a25-dihydroxyvitamin $\mathrm{D}_{3}$, $25(\mathrm{OH}) \mathrm{D}_{3}$ 25-hydroxyvitamin $\mathrm{D}_{3}$

of abnormal tracer uptake were seen in her rib on ${ }^{99}$ technetium (Tc)-methylene diphosphonate bone (MDPB) scintigraphy. Slight abnormal accumulation of tracers was observed in the NFomas located on the surface of her right forearm and left upper arm on ${ }^{111}$ indium-pentetreotide scintigraphy (Octreoscan) (Fig. 2). She did not agree with venous sampling because of difficulty in maintaining her supine position for prolonged periods because of systemic pain. Since she strongly desired resection of the NFomas on her right forearm and left upper arm, we respected her wish and excised them in February 2018. Pathology evaluation demonstrated benign NFomas. Unfortunately, there was no improvement in serum IP levels after surgery. Therefore, we administered eldecalcitol (active vitamin $\mathrm{D}_{3}$ analogue) $0.75 \mu \mathrm{g}$ per day, which also failed to produce improvement in hypophosphatemia and other abnormal data. Subsequent combination with dibasic calcium phosphate hydrate $(3.0 \mathrm{~g} /$ day $)$ led to improvement in some of the abnormalities, including hypophosphatemia: IP, $3.1 \mathrm{mg} / \mathrm{dL}$ (2.7-4.6); ALP, $209 \mathrm{U} / \mathrm{L}$ (106-322); intact PTH, $46 \mathrm{pg} / \mathrm{mL}$ (10-65); BAP, $12.4 \mu \mathrm{g} / \mathrm{L}$ (3.8-22.6); and TRACP-5b, $309 \mathrm{mU} / \mathrm{dL}$ (120-420) (data not shown). After 6 months, serum calcium, IP, intact $\mathrm{PTH}$, and BAP were $9.1 \mathrm{mg} / \mathrm{dL}, 3.6 \mathrm{mg} / \mathrm{dL}, 37 \mathrm{pg} / \mathrm{mL}$, and $14.4 \mu \mathrm{g} / \mathrm{L}$, respectively, and were stable in the normal range. Furthermore, pain also improved.

Immunohistochemical staining was performed on formalin-fixed and paraffin-embedded tissue from the resected NFomas, which demonstrated FGF23 weak

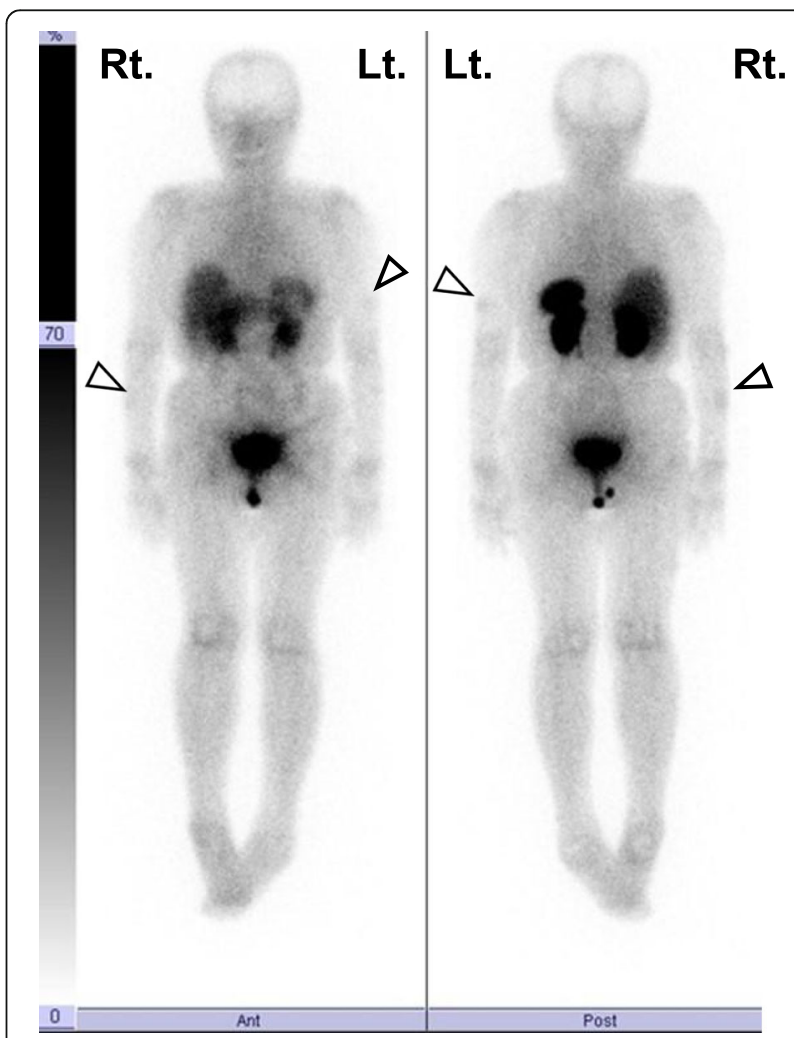

Fig. 2 Octreoscan images. The arrow heads indicate light uptake into neurofibromas located on the surface of her right forearm and left upper arm. Lt. left, Rt. right 
positivity of the NFomas (Fig. 3). Pathological processing and evaluation was performed by GenoStaff Co., Ltd. (Tokyo, Japan).

Total ribonucleic acid (RNA) extraction from the formalin-fixed paraffin-embedded tissue samples was performed according to the manufacturer's instructions. Human pancreas total RNA (Zyagen, San Diego, California, USA) was prepared as a control [7]. Next, we performed real-time polymerase chain reaction (RT-PCR) testing for housekeeping genes and actin $\beta$ gene $(A C T B)$, and the fibroblast growth factor 23 gene (FGF23), according to the manufacturers' instructions. Amplification curve plotting using fluorescence intensity by ABI PRISM SDS 2.4 (Thermo Fisher Scientific Inc., USA) was performed (Fig. 4). All samples were amplified in triplicates. Once out of three times, the threshold cycle $\left(C_{T}\right)$ value for FGF23 was 35.95 in resected NFomas, but it was not detected in human pancreas (Table 2). Unfortunately, these results did not clearly confirm expression of FGF23 in the excised NFomas. These tests were conducted by GeneticLab Co., Ltd. (Sapporo, Japan).

\section{Discussion and conclusions}

The patient described here is the first case of NF1 associated with hypophosphatemic osteomalacia, in which a high serum FGF23 level was confirmed. Our patient was a 65-year-old woman diagnosed as having NF1 at age
28. Her laboratory findings revealed hypophosphatemia due to renal phosphate wasting and a high serum level of FGF23. Her NFomas located on the surface of her right forearm and left upper arm, in which a slight abnormal accumulation of tracers was observed on Octreoscan, were surgically removed, but there was no improvement in hypophosphatemia or serum FGF23 after surgery. Immunohistochemical staining using antihuman FGF23 antibody revealed slightly positive results; however, only one out of three amplifications of the FGF23 gene was observed by RT-PCR, and no clear FGF23 gene expression in the resected NFomas could be confirmed. We administered eldecalcitol combination with dibasic calcium phosphate hydrate, which led to improvement in some of the abnormalities, including hypophosphatemia.

TIO, also known as oncogenic hypophosphatemic osteomalacia, is a rare acquired paraneoplastic disease. TIO was first described by McCance in 1947 [12]. It is usually induced by benign mesenchymal tumors secreting excessive FGF23 [13]; in fact, FGF23 has been cloned as a causative factor of TIO [7]. Approximately 500 cases of TIO were reported worldwide up to 2018 [14]. On the other hand, osteomalacia associated with NF1 was first recognized by Gould in 1918 [15]. It is extremely rare, with fewer than 50 cases being reported [6, 16-21].

In our case, the typical biochemical pattern included low serum phosphate, increased phosphate excretion in

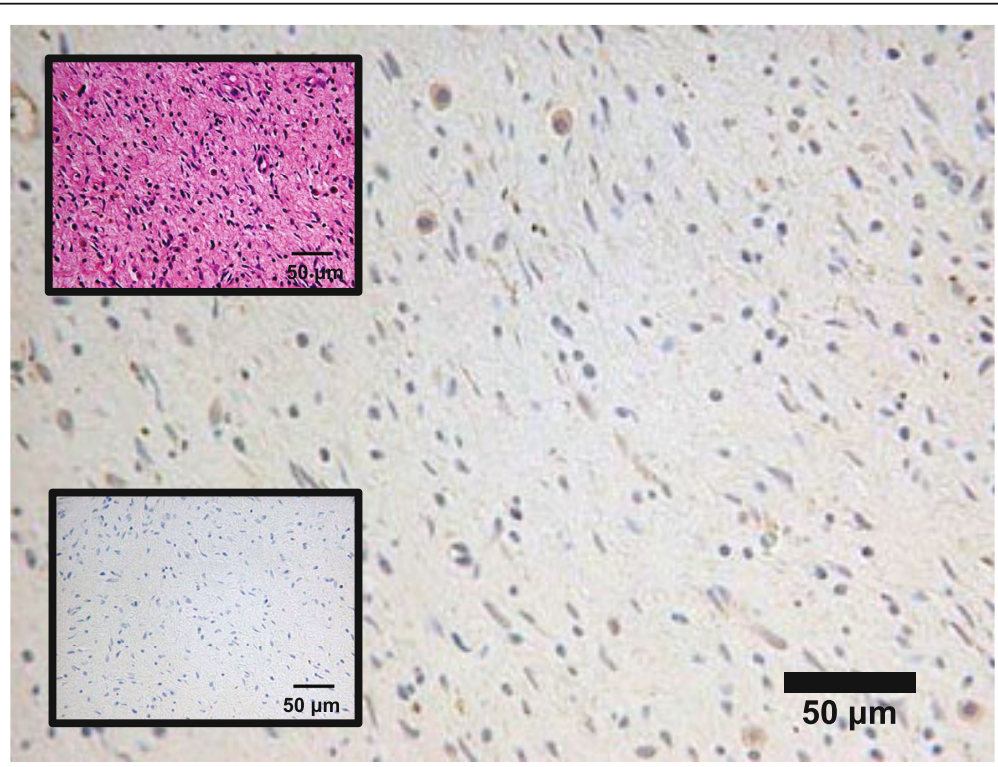

Fig. $3 \mathrm{Imm}$ unohistochemical staining of fibroblast growth factor 23 in the resected neurofibromas. Single immunolabeling (peroxidase and diaminobenzidine tetrahydrochloride) of the resected neurofibromas. The upper inset shows hematoxylin and eosin staining. Ossified metaplasia, poorly differentiated foci of cartilage tissue, and osteoclast-like giant cells contained in many mesenchymal tumors are not observed, and dense proliferation of small short spindle-shaped cells against the background of hyaline or myxoma-like stroma are observed. The lower inset shows a negative control using normal rabbit immunoglobulin. The stromal cells in the tissue stained weakly positive using polyclonal rabbit anti-human fibroblast growth factor 23 antibodies 


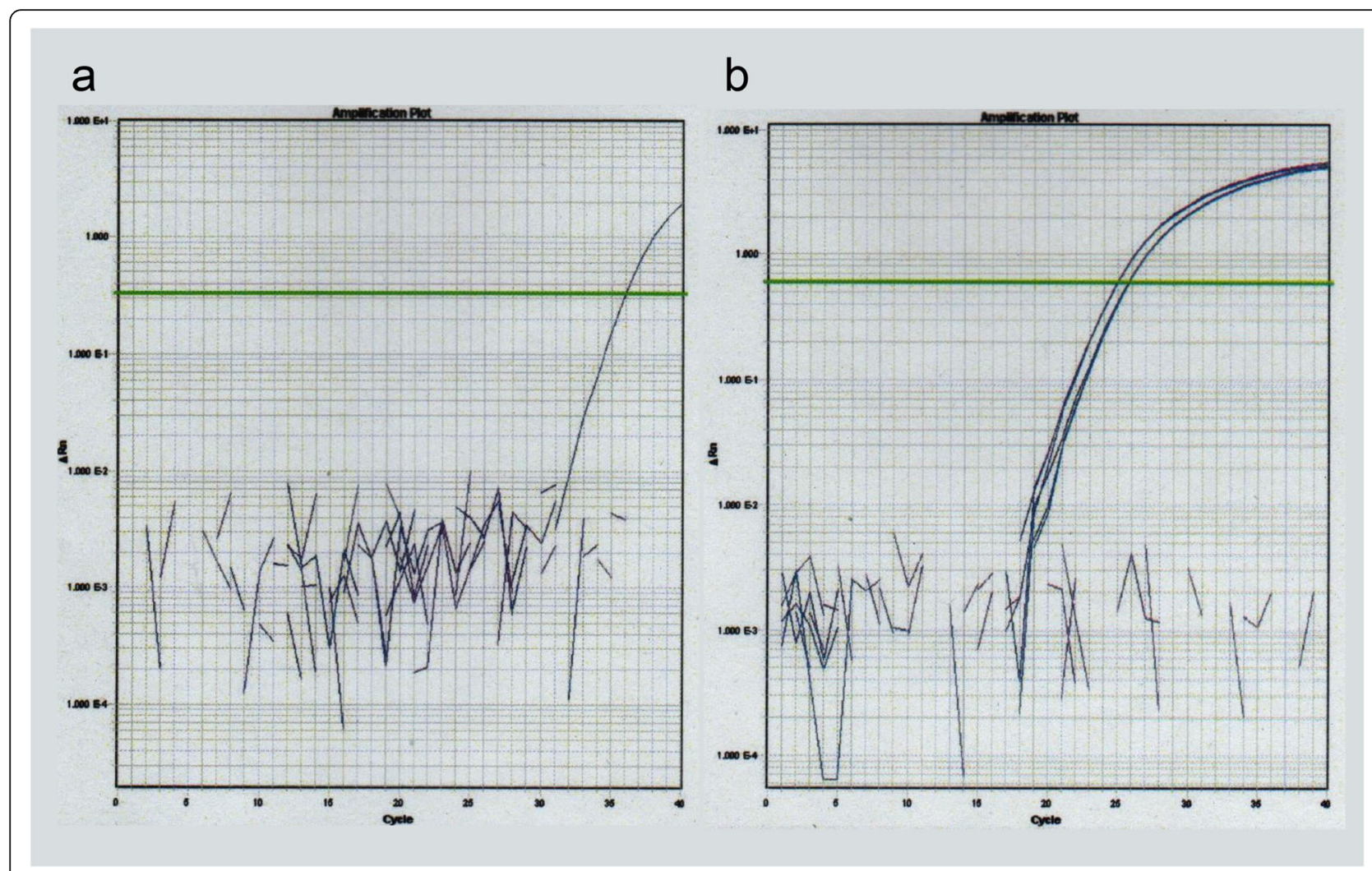

Fig. 4 Fibroblast growth factor 23 gene expression analysis by real-time polymerase chain reaction in the resected neurofibromas. Amplification curve of fluorescence intensity. Amplification curves were drawn for the fibroblast growth factor 23 (a) and actin $\beta$ (b) genes

urine with TmP/GFR reduction, and elevated ALP, BAP, TRACP $5 b$, and ucOC, indicating increased bone metabolism, along with elevated FGF23 concentrations and normal creatinine levels in serum (Table 1). We also observed elevation of serum intact PTH levels (Table 1). The serum levels of PTH are reportedly variable in TIO, although the reasons for these discrepancies remain unclear. Elevated levels of circulating FGF23 have been shown to promote the development of secondary hyperparathyroidism in predialysis patients through the suppression

Table $2 C_{T}$ value and mean $C_{T}$ value of FGF23 and ACTB by RTPCR

\begin{tabular}{|c|c|c|c|c|c|c|}
\hline \multirow[t]{2}{*}{ Sample name } & \multicolumn{3}{|c|}{ FGF23 } & \multicolumn{3}{|c|}{ ACTB } \\
\hline & $\overline{C_{T}}$ & mean $C_{T}$ & SD & $\overline{C_{T}}$ & mean $C_{T}$ & SD \\
\hline \multirow[t]{3}{*}{ Resected NFoma } & UD & - & - & 25.7 & 25.76 & 0 \\
\hline & UD & & & 25.8 & & \\
\hline & 36 & & & 25.8 & & \\
\hline \multirow[t]{3}{*}{ Human pancreas } & UD & - & - & 25 & 24.97 & 0 \\
\hline & UD & & & 25 & & \\
\hline & UD & & & 25 & & \\
\hline
\end{tabular}

ACTB actin $\beta$ gene, $C_{T}$ threshold cycle, FGF23 fibroblast growth factor 23 gene, NFoma neurofibroma, RT-PCR real-time polymerase chain reaction, SD standard deviation, UD undetermined of $1 \alpha$-hydroxylation of $25(\mathrm{OH}) \mathrm{D}_{3}$ [22], suggesting that excessive FGF23 might stimulate the parathyroid either directly or indirectly. Our patient's $1 \alpha 25(\mathrm{OH})_{2} \mathrm{D}_{3}$ levels were normal (Table 1). Since phosphate depletion stimulates renal $1 \alpha$-hydroxylation of $25(\mathrm{OH}) \mathrm{D}_{3}$, resulting in elevation of serum $1 \alpha 25(\mathrm{OH})_{2} \mathrm{D}_{3}$ concentrations, the normal level of $1 \alpha 25(\mathrm{OH})_{2} \mathrm{D}_{3}$ in this case should actually be regarded as inappropriately low levels. Low values of $25(\mathrm{OH}) \mathrm{D}_{3}$ were also observed (Table 1). Low serum $25(\mathrm{OH}) \mathrm{D}_{3}$ concentrations, as seen in our patient, have been previously described in NF1 $[17,23]$.

In our patient, a slight increase in radiotracer uptake on Octreoscan (Fig. 2) was observed in the relatively large NFomas on the surface of her right forearm and left upper arm (Fig. 1). TIO-associated tumors express a series of somatostatin receptors (SSTRs) [24, 25], and Octreoscans reportedly effectively detect occult mesenchymal tumors [26]. In recent years, it has been recommended that entire body functional imaging tests, including SSTR imaging, should be conducted first for the localization of TIOs [15]. Our experience in this case showed that NFomas are likely to produce and secrete FGF23. Octreotide $50 \mu \mathrm{g}$, however, did not inhibit FGF23 until 8 hours after its administration (data not shown). According to a previous report, the role of 
somatostatin signaling in the causation of osteomalacia by phosphaturic mesenchymal tumors is unclear, and the efficacy of the somatostatin analogue in the treatment of patients with TIO is inconsistent [27].

A previous report on NF1-associated osteomalacia showed that hypophosphatemia improved after surgical resection of two large NFomas in a patient with neurofibromatosis [18]. When we provided this information to our patient, she wanted to remove her two large NFomas. Hence, we removed the two NFomas surgically, although it did not improve the hypophosphatemia. The mechanism behind hypophosphatemia in the setting of NF1 is not known. Only one case of NF1-associated hypophosphatemic osteomalacia, in which serum FGF23 was elevated, has been reported in the past, although immunohistochemical staining did not show FGF23 expression in the NFomas [21]. In our patient, immunohistochemical staining using anti-human FGF23 antibody revealed weak positive results (Fig. 3), but we could not prove FGF23 expression in the resected NFomas by RTPCR (Fig. 4 and Table 2). The reason why hypophosphatemia was not improved by excision of the NFomas is presumed to be continued production and secretion of FGF23 from FGF23-secreting tumor of unknown location. Reportedly, oral phosphate and vitamin D therapy is effective treatment for osteomalacia associated with NF1 [6, 18]. Hence, we administered eldecalcitol, although this, by itself, did not improve hypophosphatemia or other abnormal blood parameters, making it necessary to combine it with dibasic calcium phosphate hydrate. This also suggests that vitamin D deficiency is not the main cause of hypophosphatemia in NF1.

A limitation of our report is that we do not know why the increase in FGF23 was mild in our case. In a retrospective study of 144 cases of TIOs without NF1, however, cases with normal FGF23 levels $(20.1 \mathrm{pg} / \mathrm{mL})$ were also reported [28]. Our experience suggests that under hypophosphatemic conditions, normal to mildly high levels of FGF23 might need to be considered as obviously abnormal values. In addition, the possibility that a very small amount of FGF23 is synthesized and secreted from NFomas cannot be denied. A second limitation is that the possibility of increased production of FGF23 from osteocytes cannot be denied. Kamiya et al. reported that serum FGF23 levels showed a four-fold increase in NF1 conditional knockout mice (cKO) compared with age-matched controls, and immunohistochemistry showed significantly increased FGF23 protein in the cKO bones [29]. Further evaluations about this should be conducted in future. A third limitation is that lack of venous sampling has not completely ruled out the possibility of the presence of other tumors. A fourth limitation is that the possibility of genetic hypophosphatemic rickets could not be excluded in this case.
In conclusion, we reported a first rare case of NF1 associated with hypophosphatemic osteomalacia, in which a high serum FGF23 level was confirmed.

\section{Abbreviations \\ $C_{T}$ : Threshold cycle; L2-4: Second to fourth lumbar vertebrae: \\ NF1: Neurofibromatosis type 1; NFomas: Neurofibromas; FGF: Fibroblast growth factor; FGF23: Fibroblast growth factor 23; NF1: Neurofibromatosis type 1 tumor suppressor gene; TIO: Tumor-induced osteomalacia; $25(\mathrm{OH}) \mathrm{D}_{3}$ : 25-hydroxyvitamin $\mathrm{D}_{3} ; 1 \mathrm{a} 25(\mathrm{OH})_{2} \mathrm{D}_{3}$ : 1a25-dihydroxyvitamin $\mathrm{D}_{3}$; IP: Inorganic phosphorus; TmP/GFR: Maximum transport of phosphorus in the renal proximal tubules; ALP: Alkaline phosphatase; PTH: Parathyroid hormone; BAP: Bone-specific alkaline phosphatase; TRACP 5b: Tartrate- resistant acid phosphatase $5 \mathrm{~b}$; ucOC: Undercarboxylated osteocalcin; BMD: Bone mineral density; YAM: Young adult mean; MDPB: Methylene diphosphonate bone; Octreoscan: ${ }^{111}$ indium-pentetreotide scintigraphy; RT- PCR: Real-time polymerase chain reaction; ACTB: Actin $\beta$ gene; \\ FGF23: Fibroblast growth factor 23 gene; SSTRs: Somatostatin receptors; cKO: Conditional knockout mice}

\section{Acknowledgements}

We wish to thank GenoStaff Co., Ltd., Tokyo, Japan, for the immunohistochemical staining, and GeneticLab Co., Ltd., Sapporo, Japan, for gene expression analysis by RT-PCR. We also thank the patient for her permission to publish this manuscript. Furthermore, we thank medical editing services on Forte, Inc.

\section{Authors' contributions}

TO, NK, and AT attended to the patient; TO and NK wrote the manuscript; $\mathrm{TO}, \mathrm{NK}, \mathrm{AT}, \mathrm{KO}$, and YN gave conceptual advice. NK supervised management of the case and contributed to writing and editing the manuscript. All authors have read and approved the final manuscript.

\section{Funding}

Not applicable.

\section{Availability of data and materials}

Not applicable.

\section{Ethics approval and consent to participate}

Both the removal of the neurofibromas and the immunohistochemical examinations on the excised tissue were approved by the clinical ethical review committee of Kagoshima Medical Center (Authorization number 17010, December 28, 2017). The patient gave written informed consent for the surgical procedure and subsequent evaluation of the tissue.

\section{Consent for publication}

Written informed consent was obtained from the patient for publication of this case report and any accompanying images. A copy of the written consent is available for review by the Editor-in-Chief of this journal.

\section{Competing interests}

The authors declare that they have no competing interests.

\section{Author details}

${ }^{1}$ Department of Diabetes and Endocrine Medicine, National Hospital Organization Kagoshima Medical Center, 8-1 Shiroyama-cho, Kagoshima 892-0853, Japan. ²Department of Diabetes and Endocrine Medicine, Kagoshima University Graduate School of Medicine and Dental Sciences, Kagoshima University, 8-35-1 Sakuragaoka, Kagoshima 890-8520, Japan.

Received: 21 January 2020 Accepted: 25 March 2020

Published online: 09 May 2020

\section{References}

1. Wallace MR, Marchuk DA, Andersen LB, Letcher R, Odeh HM, Saulino AM, et al. Type 1 neurofibromatosis gene: identification of a large transcript disrupted in three NF1 patients. Science. 1990;249:181-6. 
2. Viskochil D, Buchberg AM, Xu G, Cawthon RM, Stevens J, Wolff RK, et al. Deletions and translocations interrupt a cloned gene at the neurofibromatosis type 1 locus. Cell. 1990;27:1654-9.

3. Friedman JM. Neurofibromatosis 1. In: Adam MP, Ardinger HH, Pagon RA, Wallace SE, Bean LJH, Stephens K, Amemiya A, editors. GeneReviews. Seattle: University of Washington; 1998. p. 1993-2019.

4. Szudek J, Birch P, Friedman J. Growth in North American white children with neurofibromatosis 1 (NF1). J Med Genet. 2000;37:933-8.

5. Illes T, Halmai V, de Jonge T, Dubousset J. Decreased bone mineral density in neurofibromatosis-1 patients with spinal deformities. Osteoporosis Int. 2001;12:823-7.

6. Konishi K, Nakamura M, Yamakawa H, Suzuki H, Saruta T, Hanaoka H, et al. Hypophosphatemic osteomalacia in von Recklinghausen neurofibromatosis. Am J Med Sci. 1991;301:322-8.

7. Shimada T, Mizutani S, Muto T, Yoneya T, Hino R, Takeda S, et al. Cloning and characterization of FGF23 as a causative factor of tumor-induced osteomalacia. Proc Natl Acad Sci U S A. 2001;98:6500-5.

8. ADHR Consortium. Autosomal dominant hypophosphataemic rickets is associated with mutations in FGF23. Nat Genet. 2000;26:345-8.

9. Liu S, Guo R, Simpson LG, Xiao ZS, Burnham CE, Quarles LD. Regulation of fibroblastic growth factor 23 expression but not degradation by PHEX. J Biol Chem. 2003;278:37419-26.

10. Chong WH, Molinolo AA, Chen CC, Collins MT. Tumor-induced osteomalacia. Endocr Relat Cancer. 2011;18:R53-7.

11. Fukagawa M, Nii-Kono T, Kazama JJ. Role of fibroblast growth factor 23 in health and chronic kidney disease. Curr Opin Nephrol Hypertens. 2005;14:325-9.

12. McCance RA. Osteomalacia with Looser's nodes (Milkman's syndrome) due to the raised resistance to vitamin $\mathrm{D}$ acquired about the age of 15 years. Q J Med. 1947;16:33-47.

13. Koriyama N, Nishimoto K, Kodama T, Nakazaki M, Kurono Y, Yoshida H, et al. Oncogenic osteomalacia in a case with a maxillary sinus mesenchymal tumor. Am J Med Sci. 2006;332:142-7.

14. Yin Z, Du J, Yu F, Xia W. Tumor-induced osteomalacia. Osteoporosis Sarcopenia. 2018:4:119-27.

15. Gould EP. The bone changes occurring in von Recklinghausen's disease. Quart J Med. 1918;11:221-7.

16. Ben-Baruch D, Ziv Y, Sandbank J, Wolloch Y. Oncogenic osteomalacia induced by schwannoma in a patient with neurofibromatosis. Eur J Surg Oncol. 1994;20:57-61.

17. Abdel-Wanis ME, Kawahara N, Tomita K. The association of neurofibromatosis 1 and spinal deformity with primary hyperparathyroidism and osteomalacia: might melatonin have a role? J Orthop Sci. 2001;6:193-8.

18. Soveid M. Tumor associated osteomalacia in neurofibromatosis: case report and literature review. MJIRI. 2003;16:227-30.

19. Chadha M, Singh AP, Singh AP. Hypophosphataemic osteomalacia in neurofibromatosis. Acta Orthop Belg. 2009;75:847-50.

20. Gupta A, Dwivedi A, Patel P, Gupta S. Hypophosphatemic osteomalacia in von Recklinghausen neurofibromatosis: Case report and literature review. Indian J Radiol Imaging. 2015;25:63-6.

21. Sahoo SK, Kushwaha P, Bharti N, Khedgikar V, Trivedi R, Agrawal V, et al. Elevated FGF23 in a patient with hypophosphatemic osteomalacia associated with neurofibromatosis type 1. Bone. 2019; https://doi.org/10. 1016/j.bone.2019.115055.

22. Shigematsu T, Kazama JJ, Yamashita T, Fukumoto S, Hosoya T, Gejyo F, et al. Possible involvement of circulating fibroblast growth factor 23 in the development of secondary hyperparathyroidism associated with renal insufficiency. Am J Kidney Dis. 2004:44:250-6.

23. Lammert M, Friedman JM, Roth FJ, Friedrich RE, Kluwe L, Atkins D, et al. Vitamin $D$ deficiency associated with number of neurofibromas in neurofibromatosis 1. J Med Genet. 2006;43:810-3.

24. Reubi JC, Waster B, Laissue JA, Gebbers JO. Somatostatin and vasoactive intestinal peptide receptors in human mesenchymal tumors: in vitro identification. Cancer Res. 1996;56:1922-31.

25. Houang M, Clarkson A, Sioson L, Elston MS, Clifton-Bligh RJ, Dray M, et al. Phosphaturic mesenchymal tumors show positive staining for somatostatin receptor 2A (SSTR2A). Hum Pathol. 2013:44:2711-8.

26. Jan de Beur SM, Streeten EA, Civelek AC, McCarthy EF, Uribe L, Marx SJ, et al. Localisation of mesenchymal tumours by somatostatin receptor imaging. Lancet. 2002;359:761-3.

27. Łebek-Szatańska A, Papierska L, Marcinowska-Suchowierska E, Nowak KM, Zgliczyński W, Misiorowski W. Positive somatostatin receptor imaging does not predict somatostatin analogue efficacy in tumor-induced osteomalacia. Pol Arch Intern Med. 2018;128:554-5.

28. Feng J, Jiang Y, Wang O, Li M, Xing X, Huo L, et al. The diagnostic dilemma of tumor induced osteomalacia: a retrospective analysis of 144 cases. Endocr J. 2017;64:675-83.

29. Kamiya N, Yamaguchi R, Aruwajoye O, Kim AJ, Kuroyanagi G, Phipps M, et al. Targeted disruption of NF1 in osteocytes increases FGF23 and osteoid with osteomalacia-like bone phenotype. J Bone Miner Res. 2017;32:1716-26.

\section{Publisher's Note}

Springer Nature remains neutral with regard to jurisdictional claims in published maps and institutional affiliations.
Ready to submit your research? Choose BMC and benefit from:

- fast, convenient online submission

- thorough peer review by experienced researchers in your field

- rapid publication on acceptance

- support for research data, including large and complex data types

- gold Open Access which fosters wider collaboration and increased citations

- maximum visibility for your research: over $100 \mathrm{M}$ website views per year

At $\mathrm{BMC}$, research is always in progress.

Learn more biomedcentral.com/submissions 